\title{
THE UNITED NATIONS AND EAST TIMOR
}

Ten years after the Indonesian government officially incorporated East Timor as a province of the Republic of Indonesia, international attention has again been focused on Indonesia's occupation of the territory. US President Ronald Reagan's plans to visit Bali in May of 1986 prompted many members of the US Congress to urge him to raise the issue of human rights violations by Indonesian troops in East Timor with Indonesian President Suharto. The letter to President Reagan signed by 122 members of Congress, dated Apri1 29, 1986 ran as follows:

Dear Mr. President:

We continue to be deeply concerned about the human tragedy in East Timor, the predominantly Roman Catholic former Portuguese colony invaded by Indonesia in 1975. Since then, an estimated 100,000 East Timorese--nearly one-sixth of East Timor's original population--have perished from the combined effects of the Indonesian occupation. Armed conflict in the territory persists, as do reports of atrocities such as disappearances, summary executions, torture, and forced birth control.

Highly regarded international church sources confirm that serious human rights abuses continue. While there has been some ostensible improvement in access to East Timor by international humanitarian agencies, such access remains 1 imited. Unrestricted access is critical in light of reports that malnutrition-related deaths of children persist in at least some areas.

We therefore respectfully urge you to give serious attention to the East Timor situation in meetings that you and the Presidential party will have with Indonesian leaders during your visit to Indonesia in May. As the first U.S. President to visit Indonesia since the December, 1975 invasion of East Timor, your interest could contribute significantly to efforts that might prevent further bloodshed and misery in East Timor.

Secretary of State Shultz deserves credit for raising the issue of human rights in East Timor during his July, 1984 visit to Jakarta; that same month. Pope John Paul II expressed deep concern over the suffering of the people of East Timor. Further, in Apri1, 1985, British Prime Minister Margaret Thatcher raised humanitarian and human rights issues regarding East Timor during a visit to the Indonesian capital.

Continued fighting in the territory between the Indonesian military and the East Timorese resistance is reason for concern, coupled with persistent reports from Amnesty International and other organizations of human rights violations. Accounts of various pressures and intimidation directed at the Roman Catholic Church in East Timor by Indonesian authorities are most disturbing. Also 
troubling is the matter of political prisoners. While the official number of East Timorese political detainees has dropped, Amnesty International and others report that a significant number of detainees purportedly released have in fact been moved to less identifiable places of detention. There have been accounts of "hidden" prisons and detention camps to which international humanitarian groups still do not have access.

Further alarming is the news of a population 1 imitation program introduced in East Timor by the Indonesians. Authoritative church sources say that this program is being carried out often without the consent or knowledge of the mostly rural population of East Timor. A program of this nature carried out by the invaders themselves has troubling implications, considering the huge death toll in East Timor since the invasion and the comparatively small original population. Mr. President, we ask you to urge the Indonesian government to put an end to population limitation measures and practices in East Timor that do not have the full consent and knowledge of those directiy concerned.

We seek efforts to ensure the continuation and expansion of access to East Timor by International humanitarian agencies, with guarantees of freedom of movement for these agencies so that the full range of their activities may be carried out to the greatest possible extent. In particular, all prisoners and detainees should be assured timely visitation. In addition, we strongly believe that the Roman Catholic Church in East Timor should be guaranteed an existence free from official pressure and intimidation. Finally, the United States should encourage efforts to bring about a fair and peaceful settlement of the East Timor conflict.

We fully appreciate the importance of friendly relations with Indonesia. We are also aware that there will be many other issues on your agenda when you travel to Bali. However, we respectfully ask you to add the plight of the people of East Timor to your agenda. You have a special opportunity to bring to bear on the Timor tragedy the prestige and moral influence of the United States.

Sincerely,

Tony P. Hal7 (D-OH)

Robert K. Dornan (R-CA)

Claude Pepper (D-FL)

George C. Wortley (R-NY)

William H. Gray, III (D-PA)

Helen Delich Bentley (R-MD)

Joe Moak ley (D-MA)

Tony Coelho (D-CA)

Mary Rose Oakar (D-OH)

Barbara Boxer (D-CA)

Barney Frank (D-MA)

Gus Savage (D-IL)

Robert J. Mrazek (D-NY)

Edolphus Towns (D-NY)

Peter H. Kostmayer (D-PA)

Gerry E. Studds (D-MA)

$J$ im Moody (D-WI)

Doug Walgren (D-PA)
Howard L. Berman (D-CA)

Mike Lowry (D-WA)

Waiter E. Fauntroy (D-DC)

James J. Howard (D-NJ)

Fernand J. St Germain (D-RI)

Julian C. Dixon (D-CA)

Parren J. Mitchell (D-MD)

Thomas J. Tauke (R-IA)

Berk Tey Bedel1 (D-IA)

Fortney H. Stark (D-CA)

Joe Kolter (D-PA)

$\mathrm{J}$ im Cooper (D-TN)

Steny $H$. Hoyer (D-MD)

Thomas A. Daschle (D-SD)

William Hill Boner (D-TN)

Ron Wyden (D-OR)

Norman $Y$. Mineta ( $D-C A$ )

Sala Burton (D-CA) 
Barbara B. Kennelly (D-CT)

John M. Spratt, Jr. (D-SC)

Timothy $E$. Wirth (D-CO)

Bob Carr (D-MI)

Martin Frost (D-TX)

Christopher H. Smith (R-NJ)

Matthew F. McHugh (D-NY)

Frank Horton (R-NY)

Howard Wolpe (D-MI)

John Edward Porter (R-IL)

$A 7$ an wheat (D-MO)

Byron L. Dorgan (D-ND)

Douglas $H$. Bosco (D-CA)

Robert A. Roe (D-NJ)

Robert T. Matsui (D-CA)

Ronald V. Dellums (D-CA)

John $F$. Seiberling ( $D-O H)$

Tommy $F$. Robinson (D-AR)

$V$ ic Fazio (D-CA)

James L. Oberstar (D-MN)

Morris K. Udall (D-AZ)

Charles E. Schumer (D-NY)

Bob Edgar (D-PA)

Henry A. Waxman (D-CA)

Sam Gejdenson (D-CT)

William J. Hughes (D-NJ)

Robert W. Kastenmeier (D-WI)

David E. Bonior (D-MI)

Gary L. Ackerman (D-NY)

Edward $F$. Feighan $(D-O H)$

Mervyn M. Dymally (D-CA)

Bruce A. Morrison (D-CT)

Chester G. Atkins (D-MA)

Benjamin A. Gilman (R-NY)

Earl Hutto (D-FL)

John Conyers, Jr. (D-MI)

Martin 01av Sabo (D-MN)

Austin J. Murphy (D-PA)

Thomas R. Carper (D-DE)

Donald J. Pease (D-OH)

Gerry Sikorski (D-MN)

$\mathrm{J}$ im Bates (D-CA)

Leon E. Panetta (D-CA)
James Weaver (D-OR)

Mickey Lel and (D-TX)

Rod Chandler (R-WA)

Edward $P$. Boland (D-MA)

Silvio 0. Conte (R-MA)

Peter W. Rodino, Jr. (D-NJ)

Claudine Schneider (D-RI)

Tom Lantos (D-CA)

Mike Synar (D-OK)

Nicholas Mavroules (D-MA)

Lane Evans (D-IL)

William Lehman (D-FL)

Robert Garcia (D-NY)

Charles A. Hayes (D-IL)

Anthony $C$. Bellenson (D-CA)

Bruce F. Vento (D-MN)

Don Edwards (D-CA)

William Clay (D-MO)

Matthew G. Martinez (D-CA)

Albert G. Bustamante (D-TX)

Mel Levine (D-CA)

Thomas M. Foglietta (D-PA)

Patricia Schroeder (D-CO)

Brian J. Donnel ly (D-MA)

Marcy Kaptur (D-OH)

Thomas J. Manton (D-NY)

Major R. Owens (D-NY)

Thomas J. Downey (D-NY)

$J$ ames $H$. Scheuer (D-NY)

George Miller (D-CA)

Stewart B. McKinney (R-CT)

Stephen L. Neal (D-NC)

Douglas Applegate (D-OH)

Thomas A. Luken ( $D-O H$ )

John McCain (R-AZ)

Ted Weiss (D-NY)

Dave McCurdy (D-OK)

Lou is Stokes $(\mathrm{D}-\mathrm{OH})$

Bill Richardson (D-NM)

Dan Glickman (D-KS)

Bill Green (R-NY)

Augustus $F$. Hawk ins (D-CA)

Edward J. Markey (D-MA)

Six days earifer, on April 23, 1986, twenty-one US Senators had signed the following letter to Secretary of State George Shultz:

Dear Mr. Secretary:

We commend you for publicly expressing United States concern for human rights in East Timor during your Apri1, 1984 visit to Indonesia. Since that visit, British Prime Minister Margaret Thatcher and Pope John Paul II, among others, have expressed a similar concern to President Soeharto. The repeated raising of the issue by world leaders has led to some improvement of the human rights situation in East Timor, but a number of serious problems remain. 
As you know, violence and repression have plagued East Timor since the 1975 Indonesian invasion of the island. The United States should continue to encourage an equitable and peaceful resolution to the ongoing armed conflict in East Timor. The immediate problems faced by the East Timorese, however, al so demand attention. Specifical 1y:

1. While public pressure has led to the release of some political prisoners, Amnesty International reports that many of those said by the government to have been released have in reality been transferred to secret detention camps. International humanitarian organizations do not have access to these "resettlement centers" because the Indonesian government does not acknowledge their existence. Since these political prisoners are isolated from world attention, the Indonesian government need not abide by international standards governing the treatment of prisoners. Many reports of torture in these "resett]ement centers" have been received by Amnesty International.

2. The occupying Indonesian forces reportedly continue to intimidate both clergy and church members of East Timor's Roman Catholic Church. For the predominantly Roman Catholic East Timorese, such pressure only increases the tension between themselves and the Indonesians.

3. Though the famine in East Timor has ended, malnutrition and related health problems still exist in some areas. A lack of cooperation between Indonesian authorities and international relief agencies could spell disaster for the East Timorese.

4. When Portugal granted East Timor its independence in 1975, many families were separated. Those East Timorese still waiting to join their relatives in Portugal have suffered from unnecessarily slow action by Indonesian officials. Resolution of these family reunification cases would be an important humanitarian gesture by Indonesia.

We respectfully urge you to raise these concerns with the Indonesian government during your upcoming visit to the annual ASEAN meeting. We recognize the value of the relationship between Indonesia and the United States. Our friendship with Indonesia can only be strengthened by forthright discussion of the ongoing problems faced by the people of East Timor.

Thank you for your attention to this important issue.

Bill Bradley (D-NJ)

Quentin Burdick (D-ND)

John Chafee (R-RI)

Alfonse D'Amato (R-NY)

Daniel Patrick Moynihan (D-NY)

Orin Hatch (R-UT)

John Kerry (D-MA)

George Mitchell (D-ME)

Christopher Dodd (D-CT)

William Proxmire (D-WI)

Charles Grassley (R-IA)

\author{
Sincerely, \\ John Heinz (R-PA) \\ Don Reigle (D-MI) \\ Tom Hark in (D-IA) \\ Edward Zorinsky (D-NE) \\ Paul simon (D-IL) \\ Patrick Leahy (D-VT) \\ Paul Sarbanes (D-MD) \\ Albert Gore (D-TN) \\ Claiborne Pell (D-RI) \\ $A 7$ an Cranston (D-CA)
}


Since the President refused to raise the East Timor issue with President Suharto, the Congress took further action: 133 members co-sponsored a resolution deploring the situation in East Timor and calling on Secretary Shultz to express US concern to the Indonesian foreign minister during the ASEAN meetings in Manila on June 24, 1986.

The United Nations had first addressed the issue of East Timor on December 11, 1975, only four days after the Indonesian invasion. The General Assembly then adopted a resolution recognizing the rights of East Timor's people to self-determination, freedom, and independence. This resolution, passed by a vote of 69 to 11 , deplored Indonesia's military intervention and called on the Indonesian government to withdraw its forces from the territory of East Timor. Among the thirty-eight countries abstaining were the United States, the United Kingdom, France, and West Germany. Although this resolution was reaffirmed annualiy unti? 1981, voting support for it was gradually eroded and in 1982 there was a majority of only four for a weakened resolution.

Indonesian forces launched a new military offensive in september 1983, but this failed to destroy Fretel in (the Revolutionary Front for the Independence of East Timor), which heads the main armed opposition to the Indonesian occupation. 1 In fact there has been some evidence that armed resistance against Indonesian forces has increased since then.

The UN Secretary-General Javier Perez de Cuellar has attempted to reach some solution to the problem of East Timor by promoting talks between Indonesia and Portugal which the UN majority still considers the administering power there. Fretelin made clear its support for UN mediation; but it opposed the Indonesian-Portuguese talks held at the end of 1984 because they excluded representatives from the people of East Timor. It stressed that mediation should be in accordance with the United Nations' principle of self-determination. This view has received support from seventy-five members from both houses of the Japanese Diet who on April 18, 1986 sent the following letter to the Secretary-General:

United Nations Secretary General

Mr. Javier Perez de Cuellar

Dear Secretary General,

As you are aware, a full decade has now passed since the invasion of East Timor by Indonesian troops. We address you today because we believe in your sincere desire to work toward a just and lasting settlement of the East Timor conflict, a conflict which has already claimed an enormous toll in human 1ife, both East Timorese and Indonesian.

We fully support the mandate given to you in General Assembly Resolution $37 / 30$ "to initiate consultations with all parties directly concerned" with a view to achieving a comprehensive settlement of the East Timor problem. We can also well appreciate the great difficulty and delicacy of your task.

1. For an analysis of the Timor problem from the perspective of Fretel in's representative to the United Nations, see Jose Ramos-Horta, Funu: The Unfinished Saga of East Timor (Trenton, NJ : Red Sea Press). 
We are disturbed, however, to note that representatives of the East Timorese have yet to be included in these deliberations. Earlier this year you reportediy stated in press conferences in Jakarta and Tokyo that discussions between "both sides" (Indonesia and Portugal) appeared to be moving toward a solution of the fate of the East Timorese. Surely you will agree that discussions which do not include the East Timorese, notably FRETILIN, could not possibly lead to any meaningful solution of the fate of those same East Timorese.

Understandably you are anxious to work toward a speedy solution of this conflict. However, a cosmetic solution which ignores the fundamental right of the East Timorese to determine their own fate can only prolong the conflict. Furthermore, such a "solution of convenience," in contradiction to the very principles upon which the United Nations was founded, could not but be viewed as an act of cynicism by the peace-loving people of the world.

We therefore urge you to include, at earliest possible moment, representatives of the East Timorese, notably FRETILIN, in the negotiation process.

Finally, as you know, since 1975 Japan has consistently voted in the United Nations Fourth Committee and General Assembly aga inst resolutions affirming the right of the East Timorese to self-determination. The fact that the Japanese government has taken this position without adequate survey of the situation and without any discussion of the matter in this country is deeply regrettable. I pledge, therefore, to make every effort to widely publicize this pressing issue, an issue that involved the fate of an entire people, and to actively work to bring about a constructive contribution on the part of Japan.

$$
\text { Respectfully, }
$$

Japan Socialist Party

(Members of the House of Representatives)

$\begin{array}{lll}\text { Takako Doi } & \text { Hironori Inoue } & \text { Man-kichi Katoh } \\ \text { Haruo Okada } & \text { Kifchi Murayama } & \text { Tomifchi Murayama } \\ \text { Tamio Kawakami } & \text { Masao Nakamura } & \text { Takumi Ueda } \\ \text { Yasuko Takemura } & \text { Tohru Oh-Hara } & \text { Issei Inoue } \\ \text { Shu-zoh Yasuda } & \text { Shin-nen Tagaya } & \text { Masao Sakon } \\ \text { Nobuyuki Sekiyama } & \text { Sukio Iwatare } & \text { Sadao Wada } \\ \text { Matsuo Kodama } & \text { Shigeru Itoh } & \text { Toshiaki Yokoyama } \\ \text { Shun Oh-Ide } & \text { Toshiharu Okada } & \text { Tsuruo Yamaguchi } \\ \text { Haruyoshi Hosoya } & \text { Tsuyoshi Suzuki } & \text { Toyoji Shirochi } \\ \text { Sigeru Gotoh } & \text { Noboru Yagi } & \text { Chu-ryoh Morif } \\ \text { Sanji Mutoh } & \text { Kazuo Okuno } & \text { Hideyoshi Hirose } \\ \text { Masao Hori } & \text { Kanji Kawasaki } & \text { Ichiroh Hino } \\ \text { Masahiro Yamamoto } & \text { Selichi Inaba } & \text { Yu-saku Yayama } \\ \text { Ken-ichi Ueno } & \text { Ju-koh Nakamura } & \text { Torao Takasawa } \\ \text { Aogu Matsumae } & \text { Kazuhiko Tsuji } & \text { Seiichi Katsumata } \\ \text { Taneaki Tanami } & \text { Shohgo Ogawa } & \text { Kanju Satoh } \\ \text { Bun Takebe } & \text { Takatoshi Fujita } & \end{array}$


(Members of the House of Councilors)

$\begin{array}{lll}\text { Cho-zoh Akiyama } & \text { Wataru Kubo } & \text { Hideyuki Seya } \\ \text { Tadashi Yaolta } & \text { Akira Ono } & \text { Shiroh Takeda } \\ \text { Tomoyuki Fukuma } & \text { Tatsuroh Matsumae } & \text { Terumi Kasuya } \\ \text { Akira Nakamura } & \text { Michitada Takasugi } & \text { Manae Kubota } \\ \text { Jin-ichi Katayama } & & \end{array}$

United Social Democratic Party

$\begin{array}{cc}\begin{array}{c}\text { (Members of the House } \\ \text { of Representatives) } \\ \text { Satsuki Eda } \\ \text { Naoto Kan } \\ \text { Shogo Abe }\end{array} & \begin{array}{c}\text { (Member of the House } \\ \text { of Councilors) } \\ \text { Hideo Den }\end{array} \\ \begin{array}{c}\text { Komei Party } \\ \text { of Representatives) } \\ \text { Yu-ichi Ichikawa }\end{array} & \begin{array}{c}\text { (Member of the House } \\ \text { of Councilors) }\end{array} \\ \text { Sho-zoh Kusakawa } & \text { Takayoshi Wada } \\ \text { Democratic Socialist Party } & \text { New Liberal Party } \\ \text { (Member of the House } & \text { (Member of the House } \\ \text { of Representatives) } & \text { of Representatives) } \\ \text { Roh Watanabe } & \text { Kohki Chuma } \\ \text { Salaryman Shintoh } & \text { Shinsei Club } \\ \text { (Members of the House } & \text { (Member of the House } \\ \text { of Councliors) } & \text { of Councilors) } \\ \text { Shigeru Aoki } & \text { Tokuma Utsunomiya } \\ \text { Heihachiroh Kimoto } & \end{array}$

As East Timor reemerged as an important topic of international debate it appeared again on the United Nations agenda. On August 15, 1986, the UN Special Committee on Decolonization held hearings on East Timor, where an Indonesian representative, Mr. S. Wiryono, presented his government's position, and documents were put forward by representatives of the following groups:

British Campaign for the Defence of Political Prisoners and Human Rights in Indonesia

Indonesia East Timor Program (Canada)

Amnesty International

Asia Watch

Society for Threatened Peoples

Komitee Indonesie

Catholic Institute for International Relations

(UK) Parliamentary Human Rights Group

Christian Conference of Asia

Hobart East Timor Committee

International League for the Rights and Liberation of Peoples

La Comunidad de Refugiados del Timor Oriental Residentes en Australia

Australia Council for Overseas Aid

Canada Asia Working Group

Comissao Para Os Direitos do Povo Maubere 
and by the following individuals:

Professor Benedict R. Anderson

Jose Ramos Horta

Monsignor Martinho da Costa Lopes

Professor El izabeth Traube

Most of the documents presented were concerned with the specifics of human rights violations by Indonesian occupation forces, but the following statement may be of more general interest to readers of Indonesia as it provides a broader view of the current situation in East Timor, and compares the relationship between the UN and the East Timorese struggle today with that between the UN and the Indonesian independence struggle in 1945-49.

\section{Statement by Benedict R. O'G. Anderson}

Mr. Chairman, distinguished delegates,

It is now almost eleven years since the military regime in Jakarta launched its invasion of East Timor, and more than ten since the rubber-stamp Indonesian parliament passed a bill formally incorporating that country into Indonesia as its twenty-seventh province. Yet, as Murray Kempton, the most eminent of American journalists, noted last November: "Indonesia now has as many and possibly more troops in East Timor than on the day of the initial invasion. - . Indonesia explains that the Timorese are pacified and content and grateful for their new roads and new literacy. There are, it concedes, 200 or so guerrillas still resisting--with unheard of vehemence and pertinacity, we may assume, since it takes a 10,000 member army to contain them."2

The best explanation for this situation was unwittingly given by no less than President Suharto in the course of last year's Independence Day address to the Indonesian nation. On that occasion he said: "A fighter in the struggle, whose slogan is 'once a fighter, always a fighter,' will never cease fighting for the nation's ideals so long as he is alive." 3 He was of course referring to Indonesia's own four-year-long struggle for independence from Dutch colonialism (in which he himself played an active and honorable part), a struggle which involved much death and destruction, though nothing comparable to what suharto has visited on the East Timorese. The tragedy is that he has always obdurately overlooked the truth of his own words when dealing with the nation of East Timor.

What is the condition of East Timor today, after eleven years of foreign occupation? Reliable information is difficult to obtain. Nothing better demonstrates the failure of the Suharto regime's policies and its bad conscience over the suffering it has inflicted on the people of East Timor than the fact that it keeps the country in the strictest isolation it can manage. Few foreigners have been permitted entry, and none has been allowed to travel freely or talk frankly with the local people. Even Indonesians are required to have permits to enter what the regime claims is part of their own motherland. 4 East Timor has no local press, and it is impossible to make long distance telephone

2. Washington Post, November 18, 1985. Most of the quotations cited in these footnotes can be found in Indonesia Reports (available from Indonesia Publications, North College Park Station, P.0. Box 895, College Park, MD 20740).

3. Asian Wall Street Weekly, August 26, 1985.

4. See Andree Feillard's report in Asiaweek, July 14, 1985. 
calls in or out of the country. 5 The surrounding seas are strictly patrolled, and the overwhelming bulk of the 1,000 or so passengers who fly in and out of Dili each month ${ }^{6}$ are civilian eccupation officials, of whom about 15,000 are now stationed in the territory. The Indonesian press itself operates under tight government controls so that the Indonesian reading public has oniy the sketchiest idea of what is going on.

Nonetheless, a good deal can be learned from unwary statements by Indonesian officials themselves. In significant ways these statements confirm what Amnesty International, representatives of the free East Timorese people, and various academic observers have already, or will shortly, be describing to you.

We may begin by noting that according to the Indonesian regime's own census figures for 1980, the population of East Timor was then $555,350 .^{8}$ By contrast, the Portuguese colonial census of 1970 gave a population of 609,477 , and census officials in 1974 estimated that by then the figure had risen to about $650,000.9$ Thus in the six years between 1974 and 1980 , by conservative estimate, approximately 100,000 East Timorese, or 15 percent of the population, were wiped out by war, famine, and associated disease. A comparable percentage of the population of the United States today would mean 36,000,000 dead. The inferences to be drawn from the censuses are confirmed by Mario Carrascalao, the Suharto regime's governor in Dili, who last year told Reuters' correspondent Peter Millership that at least 100,000 East Timorese had died untimely deaths since 1975. El sewhere he spoke of 20,000 orphans, 11,000 abandoned children, and 8,000 crippled or maimed. 11 For America, this would be equivalent to $8,600,000$ orphans, 4,600,000 abandoned children and 3,600,000 crippled or maimed. Yet the immediate architect of this catastrophe, General Leonardus "Benny" Murdani, visiting the Indonestan troops in Dili last Christmas, had the effrontery to remind them that, as he put it, "The teachings of Christ are love and peace."12

Nor did the death and destruction cease after the terrible antipopulation campaigns of 1975-79. Last year's Amnesty International report 1isted the "disappearance" of at least 550 East Timorese noncombatant civilians since 1979. For this and other reasons, which Amnesty has amply documented, the Nobel-Prize winning organization--which, I note, has never been permitted to conduct an investigation either in Indonesia or East Timor--decided to make the case of East Timor one of its four major international campaigns last year-after eleven years of Indonesian occupation. Amnesty International does not make such decisions 1 ightly.

5. Sydney Morning Herald, December 10, 1985.

6. Statement of Arya Suparta, local Garuda Airlines manager in Dili, as cited in Sinar Harapan. April 10, 1985.

7. Report of Jacques Guilion, Agence France-Presse, July 9, 1985.

8. According to $\mathrm{J}$. Suwardiyo--by his name clearly a Javanese--who nonetheless was in 1985 head of the East Timor Department of Education and Culture. Sinar Harapan. September 13, 1985.

9. James Dunn, Timor: A People Betrayed (Milton, Queensland: The Jacaranda Press, 1983), p. 3.

10. As reported in Niugini Nius, March 11, 1985.

11. Kompas, March 20, 1985.

12. Ibid., December 26, 1985. 
What can we learn of social conditions after ten years of so-called integration into Indonesia? Again, some of the most damaging information comes to us from Indonesian state officials. The 1980 census reveals that in that year 79 percent of the East Timor population was 111 iterate, and 67 percent had no speaking use of bahasa Indonesia, the Indonesian national language--which, by the way, is an exceptionally easy language to pick up. 13 The situation has not much changed since then, to judge from a statement made last september by Clementino dos Reis Amaral, an East Timorese member of Indonesia's puppet parliament. Reporting on a visit by that parliament's Commission I to East Timor the previous month, he complained that "the use of the Indonesian language there is still uncommon."14 Ten years after integration--and in spite of General Murdani's peace and love. Last December, the secretary of the provincial government in DiTi conceded that no more than thirteen East Timorese have received BA degrees, and all were obtained outside East Timor, since there was then no university or college in the territory itself. 15 Governor Carrascalao, too, recently complained that he had no more than 1,000 native East Timorese officials who were literate- in any language. 16 Small wonder that East Timor continues to be governed by a horde of foreign, i.e., Indonesian, civil and military bureaucrats.

But even if the educational and literacy levels in integrated East Timor are so abysmally low, perhaps at least economic progress has been made? Not if a cautious pronouncement last year by the Indonesian parliament's Commission VIII is to be believed. The Commission stated that 70 percent of the province's housing failed to meet minimum health conditions; 60 percent of the territory's area was inaccessible by road; 30 percent of the population lived below even the Indonesian government's very low official poverty line; and the Ministry of Social Affairs, which is responsible for providing the state's medical and other welfare services, had not a single operational unit outside the city of Dili. 17 Ten years after integration.

But perhaps now at least normal social life has returned to East Timor? The courageous Apostolic Administrator in Dili, Monsignor Carlos Ximenes Belo, stated last year that: "People, including me, feel as if we are in a jail in our own country."18 He personally had good reason for saying so insofar as the Suharto regime took six months to grant the exit permit that would allow him to visit his spiritual superior, Pope John Paul, in Rome. 19 But even more revealing are the remarks of Governor Carrascalao, who told Asiaweek correspondent Andree Feillard in July 1985 that: "The people have not felt free in their movements. This is very much against the habits of the East Timorese. The Timorese are no longer people who can talk openly to each other. . . The Timorese can not [even] produce food the way they would 1 ike." 20 What he meant by the final, somewhat cryptic words can be inferred from an additional comment he made that

13. Sinar Harapan, September 13, 1985.

14. Angkatan Bersenjata and Surabaya Post, September 11, 1985.

15. Indonesian News and Views, December 1, 1985.

16. Kompas, March 20, 1985.

17. Suara Karya, Apri1 27, 1985.

18. Interview with Jacques Guilion for Agence France-Presse, August 8, 1985.

19. Ibid.

20. Asiaweek, JuTy 14, 1985. 
in the nine years between 1976 and 1985, the population of Dili increased tenfold, from 8,000 to $80,000.21$ This huge migration has certainiy not been caused by the city's bright 1 ights, but rather by intolerably oppressive conditions in the home villages of the unfortunate farmer-refugees. Ten years after integration.

To round out the picture, we may finaliy turn to the independence struggle itself. Other witnesses present here today will be able to speak far more authoritatively on this struggle than I. But once again, we can learn a good deal from pronouncements by highly placed officials of the Suharto regime. In late January last year, these officials were loudly celebrating the surrender of a guerrilla commander named Mauk Morak, whose importance was underlined for the Indonesian press by the fact that he brought in 200 other guerrillas with him. Unluckily, a few months earlier a leading military spokesman had stated that there were no more than 200 "bandits" left in the entire country. Had this been true, Morak's surrender with his 200 men would have ended the fighting. But of course it was not true. General Murdani conceded as much last October when he told Asiaweek correspondent Feillard that all that remained was "Xanana [commander of the East Timor nationalist guerrillas] with 100, 200, 1,000 . . 2,000 men." 22 Since the last figure is twenty times larger than the first, one gets the impression that Murdani's field intelligence can not be very accurate. One notes also that the 2,000 figure is larger than anything the Suharto regime has conceded for years. Thus, if Murdani's highest estimate is correct, there are reasons for thinking that the armed resistance is getting stronger rather than weaker--an impression strengthened by the renewed appearance on the air of the guerrilla radio, and by the large numbers of Indonesian troops in East Timor. Confirmation of this impression comes from reports by two Western journalists who made brief visits to East Timor last year. Andree Feillard reported that in the Eastern sector of East Timor, only the few road links, the towns and their immediate surroundings were regarded by Indonesian officials themselves as "under full control." 23 Jacques Guillon of Agence France-Presse recorded in July 1985 that he encountered no less than thirteen military roadblocks along the 210 kilometer road between Dili and Los Palos, a part of the country supposediy completely pacified! On a visit to the military cemetery in Dili he found 84 new graves with death-dates between January 1 and July 3 , 1985. 24 What he might have discovered at other military cemeteries had he been permitted to visit them, we do not know--we do know, however, that Goyernor Carrascalao was enraged that he managed to see even the one in Dili.25 But casualties on this scale indicate that the independence struggle is very much alive. Meanwhile, Amnesty International has been documenting the summary trials of many dozens of so-called subversives. Amnesty is rightly concerned about the flagrantly abusive character of these trials, in which not a single person has been acquitted, and where defense lawyers, none of them speaking Tetum, the national language of East Timor, have spent no more than one or two weeks on each case. But we may find confirmation, precisely from the scale of these abuses, of the anxiety and insecurity of the occupying forces. If East Timor were really the satisfied, pacified, integrated place that the Jakarta regime claims it is, such busy kangaroo courts would be wholly unnecessary.

21. Jakarta Post, August 7, 1985.

22. Asiaweek, October 11, 1985.

23. Ibid., July 14, 1985.

24. Cited in the Melbourne Age, Juiy 9, 1985.

25. As Lincoln Kaye reported in Far Eastern Economic Review, Juty 20, 1985. 
I would like to summarize the conclusions that flow incontrovertibly from the data presented so far, before proceeding to the final portion of my testimony. I say incontrovertibly, because most of this data comes not from exiled East Timorese, not from representatives of Fretilin, and not from Indonesians opposed to the Suharto regime. The main source is the Suharto regime itself. If officials of this regime concede the deaths of at least 15 percent of the East Timorese population of 1975; the existence of thousands of orphans, abandoned children, as well as maimed and crippled people; overwhelming 111 iteracy; massive non-use of the Indonesian language; severe economic backwardness; a pervasive climate of fear and suspicion; strengthened guerrilla resistance; and the continuing need to isolate East Timor even from Indonesians--then we can be confident that, after eleven years of brutal military occupation, the so-called pacification has failed, not to speak of integration. 26

Let me now turn to Indonesia, and raise the question of what interests and whose interests are engaged in the continuing occupation of East Timor. The Indonesian people's perhaps? Indonesian nationalism has long been a deep and powerful force. It not only survived, but grew steadily stronger over three decades of political, and four years of armed, struggle against Dutch colonialism. In the spring of 1949, the Dutch military succeeded not only in taking control of 95 percent of the towns in Indonesia, but also captured President Sukarno, Vice-President Hatta, the head of the infant national air force, and many other leaders. In February 1949 almost no one could have imagined that by December it would all be over, with the Netherlands transferring legal sovereignty to a free Sukarno and Hatta, as President and Vice-President of the United States of Indonesia. But this is what happened. It happened partiy because Indonesian freedom-fighters continued their resistance in the rural areas, just as East Timorese freedom-fighters are doing today. It also happened because the United Nations had the courage and energy to make its presence felt, and to bring to bear the weight of world opinion. In addition, the allies of the Netherlands, most notably the United States, al so made clear that they could no longer support Dutch policies. 27

At no point in this long, courageous struggle; nor under the remarkably free liberal parliamentary regime of 1950-59; nor under President Sukarno's Guided Democracy of 1959-65, with its militant anticolonialism; nor during the first ten years of General Suharto's regime did any significant Indonesian group express the slightest interest in East Timor. Only when this tiny, 400year old Portuguese colony seemed finally about to become free, thirty years after Indonesia's own proclamation of independence, did a Jakarta government decide to intervene. This historical record shows that there is no genuine connection between Indonesian nationalism and East Timor. I can also say that I have never met an Indonesian not a government official who evinced any emotional attachment to East Timor or identified with it. And if the Indonesian government itself sincerely believed that the East Timorese were "brothers," it seems impossible to believe that it would deliberately have brought over 100,000 of them to their deaths; or would, to this day, make it so difficult for ordinary Indonesians to enter the territory of their "brothers."

26. No wonder Tempo opened its long series of texts commemorating the tenth anniversary of East Timor's formal absorption into Indonesia with these sardonic words: "Timor Timur, kini apalagi dulu, memang bukan surga." Tempo, July 19, 1986, pp. 34-37, at p. 34 .

27. See the classic account of all this given in George McT. Kahin, Nationalism and Revolution in Indonesia (Ithaca: Cornell University Press, 1952), chs. II and 13. 
Perhaps the interest was in the security of the Indonesian state? It has been said that the East Timorese were unlucky in the timing of their declaration of independence in 1975, only months after the collapse of the Thieu regime in Saigon and that of Lon $\mathrm{Nol}$ in Phnom Penh. Some observers are persuaded that these events greatly al armed the Suharto regime, which in 1965-66 had destroyed the Indonesian Communist Party, supervised the massacre of probably half a million of its supporters, and imprisoned a further million. These observers believe that Suharto's entourage genuinely feared that an independent East Timor might prove a safe haven for Indonesian subversives and even offer military facilities to hostile foreign powers. In fact, there are good reasons to be skeptical of this argument. But even if it were true, the situation has completely changed since 1975. General Murdani has repeatedly been received as an honored guest in Hanol; and while Jakarta still has no formal diplomatic ties with the CPR, trade relations flourish, and a number of high Indonesian officials have been on informal visits to Peking. Relations with the Soviet Union and the states of Eastern Europe are good, indeed Jakarta has recentiy been stressing the need for additional aid and trade. Most important of all, over the past two years General Murdani has repeatedly stated that Indonesia faces no external threat over the next decade. 28 This being the case, there is today no plausible "national security" justification for the continuing occupation of East Timor.

What then? Only two small groups in Indonesia have a real interest in the occupation. One is a clique of officials and businessmen who have made great profits from monopoly control of East Timor's superb export coffee, and hope to do still better from the oil reputed to 1 ie beneath its surrounding waters. The other is a not much larger group of senior military officers who devised and carried out the occupation, built their careers on it, and for reasons of face and power can not bear to contemplate its abandonment. They are only too aware of the fate of the Greek junta after the debacle in Cyprus, and of the Argentinian generals after the misadventure in the Malvinas. These two, small groups control Indonesian public $1 \mathrm{ife}$, but they do not represent the Indonesian people. Nor will they be around forever. There is absolutely no reason why, over the long haul, the nations of Indonesia and East Timor can not live side by side in amity--as indeed Indonesia does today with its other neighbors, Malaysia, Singapore, Brunei, the Philippines, and--with obvious qualifications (resulting from the Suharto regime's brutal treatment of the population of West Irian)--even Papua-Niugini.

The people of East Timor have suffered unimaginably for having done no more than claim those rights to self-determination on which the whole organization of the United Nations is based. It is therefore surely only right and proper for the United Nations to do now for East Timor what it did so successfully for Indonesia itself less than forty years ago.

The United Nations can do so first by reiterating and strengthening the principle of self-determination, and thus the right of the people of East Timor to decide their own political future. Conversely, it can resolutely reject any claims to legitimacy for the Suharto regime's occupation of the country.

In the second place, it can lend active support to the efforts of Portugal to fulfill honorably its decolonizing responsibilities. It is striking evidence of Portuguese concern that as recently as last December, the Portuguese parliament passed unanimously a resolution opposing further Indonesian occupation of

28. See, for example, his remarks to correspondent Feillard, reported in Asiaweek, October 11, 1985. 
East Timor. 29 I note that the Portuguese parliament is exactly the opposite of the rubber-stamp parliament in Jakarta, which is the product of rigged and manipulated elections, and over the past twenty years has not once enacted a substantial law on its own initiative. The Portuguese parliament is the product of genuinely free elections and contains representatives of every type of political view from left to right. Unanimity from this parliament on the East Timor questions indicates a popular concern about East Timor that is notably absent in Jakarta. Strong support from the United Nations would be extremely helpful to any positive Portuguese initiative. With such support, there is no reason in principle why Lisbon could not supervise a process whereby the people of East Timor could freely express their varied political views and exercise their fundamental right to self-determination.

Thirdly, the United Nations could strongly encourage Indonesia's closest friends to exert their influence and extend their good offices. As I mentioned earlier, a key factor in the successful decolonization of Indonesia in 1949 was a significant change in the policy of the United States, from more or less strong support of the Dutch position to a more sympathetic concern for Indonesia's rights--and this precisely at a time when many thought Indonesia's cause was lost. A major reason for American success in changing the policy of The Hague was, aside from longstanding ties of friendship, Washington's financial underwriting of the wartorn Dutch economy and of the war effort in Indonesia. The role played by the United States alone in 1949 can today be jointly reenacted by the United States and Japan. 30 Ninety-five percent of the military equipment used in the initial Indonesian invasion in 1975 was American--even though its use for the invasion blatantly violated the terms of the 1958 US-Indonesian bilateral arms agreement. Jakarta's main arms purchases since 1975 have been of American provenance, and most have been of a kind developed for counter-guerrilla operations. Thus the United States bears the same kind of responsibility for Indonesian aggression in 1975-86 as it bore for Dutch aggression in 1946-49. Just for this reason, however, a change in US policy would have a profound impact in Jakarta. At the same time the US and Japan have long been the major underwriters of, and investors in, the Indonesian economy. In Jakarta both Tokyo and Washington are regarded as friends, with no interest whatever in causing domestic political turmoil. All the more reason, therefore, why a change in Japanese and American positions on East Timor would be taken very seriously in Indonesia. It seems to me that the UN, and particularly those members who have the closest ties with the US and Japan, could, and should, do their utmost to encourage these two states to exert in a new, constructive way the influence they clearly have in Jakarta. The peaceful liberation of East Timor would not only end the eleven-year nightmare its people have suffered, but would also remove a grave stain on Indonesia's good name, not to speak of stopping a continuing drain on the lives of its ordinary soldiers and the resources of its hardpressed, ordinary people.

29. Diario Noticias, December 6, 1985.

30. In this regard, the letters signed by 122 US Congressmen, 21 US Senators, and 75 members of the Japanese Diet, are a significant expression of growing public concern in the two countries. 